\title{
DAYA HAMBAT DAUN ALPUKAT MUDA TERHADAP BAKTERI MULUT (STREPTOCOCCUS MUTANS)
}

\section{Prasko $^{\bowtie 1}$, Bambang Sutomo ${ }^{2}$, Suwarsono $^{3,} \operatorname{Iman}_{\text {Supardan }}{ }^{4}$}

\begin{abstract}
ABSTRAK
Karies gigi merupakan salah satu masalah kesehatan mulut yang dapat menyebabkan rasa sakit dan mengganggu aktivitas. Bakteri memainkan peran penting dalam proses karies gigi. Penyebab utama karies gigi adalah bakteri Streptococcus mutans menghasilkan enzim glukosiltransferase. Streptococcus mutans menghasilkan polisakarida ekstraseluler lengket makanan karbohidrat dan mampu memfermentasi karbohidrat menjadi asam. viridans Streptococcus adalah bakteri di mukosa yang mensintesis polisakarida besar seperti dekstran dan levans sukrosa yang merupakan faktor penting dalam pembentukan karies gigi.

Penelitian ini bertujuan untuk menentukan efektivitas konsentrasi ekstrak daun alpukat dari $60 \%$ dan $80 \%$ untuk penghambatan pertumbuhan Streptococcus mutans.

Metode yang digunakan adalah metode sumur difusi menggunakan 2 sampel di masing-masing kelompok perlakuan. Sampel terdiri dari 3 kelompok perlakuan alpukat konsentrasi ekstrak daun muda 60\%, 80\%. Metode analisis data penelitian ini menggunakan deskriptif kuantitatif.

Hasil penelitian menunjukkan bahwa ekstrak daun alpukat sama sekali konsentrasi memiliki aktivitas antibakteri terhadap Streptococcus mutans. Konsentrasi terendah 60\%, 80\% penghambatan terhadap bakteri memiliki yang kuat dan semakin kuat pada konsentrasi yang lebih tinggi. Kesimpulan dari penelitian ini membuktikan bahwa ekstrak daun alpukat memiliki aktivitas antibakteri yang kuat terhadap pertumbuhan Streptococcus mutans.
\end{abstract}

Kata kunci : Alpukat Muda Leaf, Streptococcus Mutans

\begin{abstract}
Dental caries is one of the oral health problems that can cause pain and disrupt the activities. Bacteria plays an important role in the process of dental caries. The main bacterial cause of dental caries is Streptococcus mutans producing the glucosyltransferase enzyme. Streptococcus mutans produces a sticky extracellular polysaccharides of carbohydrate foods and able to ferment carbohydrates to acids. Streptococcus viridans is bacteria in the mucosa that synthesize large polysaccharides like dextran and levans of sucrose that are important factor in the formation of dental caries.

This study aimed to determine the effectiveness of avocado leaf extract concentration of $60 \%$ and $80 \%$ to the inhibition of the growth of Streptococcus mutans.

Method used was the method of diffusion wells using 2 samples in each treatment group. Sample consisted of 3 treatment groups avocado young leaf extract concentration of $60 \%, 80 \%$. This research data analysis method using quantitative descriptive.

The results showed that the leaf extract of avocado at all concentrations have antibacterial activity against Streptococcus mutans. The lowest concentration of 60\%,80\% inhibition against the bacteria have a strong and increasingly stronger at higher concentrations. The conclusion of this study prove that avocado leaf extract has strong antibacterial activity against the growth of Streptococcus mutans.
\end{abstract}

Key words : Avocado Young Leaf, Streptococcus Mutans

\footnotetext{
$\overline{1,2,3,4)}$ Dosen Jurusan Keperawatan Gigi Poltekkes Kemenkes Semarang

$\bowtie$ :praskoabdullah@yahoo.co.id
} 


\section{PENDAHULUAN}

Undang-undang kesehatan nomor 36 tahun 2009 menyebutkan bahwa upaya kesehatan diselenggarakan dalam bentuk kegiatan dengan pendekatan promotif, preventif, kuratif, dan rehabilitatif yang dilaksanakan secara terpadu, menyeluruh, dan berkesinambungan. Penyelenggaraan upaya kesehatan tersebut dilaksanakan melalui berbagai kegiatan yang salah satunya adalah dalam bidang kesehatan gigi dan mulut.

Kegiatan penyelengaraan upaya kesehatan gigi dan mulut dapat ditempuh dengan beragam cara yang salah satunya adalah secara tradisional. Pengobatan tradisional memiliki keterkaitan yang erat dengan obat tradisional. Obat tradisional dalam Permenkes RI nomor 3 tahun 2010 adalah bahan yang berupa bahan tumbuhan, bahan hewan, bahan mineral, sediaan sarian (galenik), atau campuran dari bahan tersebut yang secara turun temurun telah digunakan untuk pengobatan, dan dapat diterapkan sesuai dengan norma yang berlaku di masyarakat.

Alpukat merupakan tanaman buah yang termasuk dalam famili Lauraceae yang tumbuh didataran dengan hawa sejuk (Anita, et al., 2005). Bagian tanaman alpukat yang memiliki banyak manfaat adalah daun alpukat. Daun alpukat mempunyai efek antifungi, antimikroba, analgesik dan antiinflamasi.

Streptococcus adalah kokus grampositif yang tersusun berpasangan atau seperti rantai (Hawley, 2003). Sedangkan Streptococcus viridans merupakan anggota flora normal yang paling umum pada saluran pernapasan bagian atas dan berperan penting untuk menjaga keadaan normal selaput mukosa. Beberapa Streptococcus viridans (misalnya $S$ mutans) menjadi faktor penting pada pembentukan karies gigi (Jawetz, dkk, 2005).

Sebuah penelitian telah membuktikan bahwa uji invitro ekstrak daun alpukat yang mengandung senyawa flavonoid dan alkaloid yang dapat menghambat penyebaran virus (HSV) herpeks simpleks (Miranda dkk, 1997). Sedangkan penelitian Hasbi (2012) tentang uji sensitivitas perasan daun alpukat (Persea americana miller) terhadap pertumbuhan bakteri Pseudomonas sp menunjukkan pemberian air perasan daun alpukat dengan konsentrasi 100\%, 80\%, $60 \%$, $40 \%$ dan $20 \%$ dapat menghambat pertumbuhan bakteri Pseudomonas sp.

Berdasarkan latar belakang diatas dapat dirumuskan permasalahan sebagai berikut ; Bagaimanakah daya hambat daun alpukat muda terhadap bakteri mulut (Streptococcus Mutans).

Tujuan dari penelitian ini adalah untuk mengetahui efektifitas ekstrak daun alpukat muda konsentrasi $60 \%$ dan $80 \%$ terhadap daya hambat pertumbuhan bakteri Streptococcus mutans.

\section{METODE PENELITIAN}

Jenis penelitian adalah eksperiment laboratoris dengan rancangan penelitian rancangan penelitian post only control design. Populasi yang digunakan adalah hasil biakan murni bakteri Streptococcus mutans yang tersedia di Laboratorium Kesehatan Daerah Semarang. Sampel yang digunakan adalah koloni Streptococcus mutans diambil dari biakan murni yang telah diisolasi dan dibiakkan dengan media Agar di Laboratorium Mikrobiologi UNNES Semarang.

Variabel pengaruh dalam penelitian ini adalah ekstrak daun alpukat muda konsentasi $60 \%$ dan $80 \%$. Variabel terpengaruh dalam penelitian ini adalah bakteri Streptococcus Mutans. Sedangkan variabel terkendali adalah media kultur PCA, waktu inkubasi 1 x 24 jam dan suhu inkubasi $37{ }^{0} \mathrm{C}$. Uji daya hambat dilakukan untuk masing-masing bakteri dengan menggunakan 3 cawan petri dengan langkah-langkah yang dilakukan sebagai berikut : 
1. Sebanyak 150 gram daun alpukat kering, dihaluskan.

2. Ekstraksi dengan metode sokletasi pelarut etanol $300 \mathrm{~mL}$

3. Sokletasi dilakukan selama kurang lebih 3 jam

4. Hasil ekstrak di uapkan pelarutnya dengan Rotary evaporator suhu penangas $80^{\circ} \mathrm{C}$

5. Ekstrak kental daun alpukat digunakan untuk uji daya hambat bakteri

Metode analisa data penelitian ini menggunakan analisis deskriptif kuantitatif yaitu mendeskripsikan hasil penelitian yang berupa angka dimana data yang diperoleh diolah dan dimasukkan dalam tabel, kemudian dihitung skor atau nilai rataratanya dan tabulasi. Kemudian dilakukan interpretasi data dan penjelasannya.

\section{HASIL DAN PEMBAHASAN}

Sudah dilakukan penelitian secara laboratories terhadap uji daya hambat bakteri Streptococcus mutans dan Streptococcus viridans dengan menggunakan ekstraksi daun alpukat.

Tabel 1. Daya hambat ekstrak daun alpukat muda dengan konsentrasi $60 \%$ terhadap pertumbuhan bakteri Streptococcus mutans

\begin{tabular}{cccc}
\hline No Pengukuran & $\begin{array}{c}\text { Daya Hambat } \\
\text { Terhadap Bakteri } \\
\text { Dengan Etrak Daun } \\
\text { Apukat (mm) }\end{array}$ & $\begin{array}{c}\text { Daya Hambat } \\
\text { Bakteri Pada } \\
\text { Kelompok } \\
\text { Kontrol } \\
(\mathrm{mm})\end{array}$ \\
\hline 1 & $\mathrm{U} 1$ & 28,4 & \\
\hline 2 & $\mathrm{U} 2$ & 25,3 & 18,9 \\
\hline 3 & $\mathrm{U} 3$ & 21,4 & \\
\hline RATA-RATA & 25,03 & \\
\hline
\end{tabular}

Tabel diatas menunjukkan bahwa zona blank setelah dilakukan perlakuan dengan konsentrasi $60 \%$ menunjukkan nilai rata-rata $25,3 \mathrm{~mm}$, dimana area terkecil pada $21,4 \mathrm{~mm}$, sedangkan area terluas $25,3 \mathrm{~mm}$. Kondisi ini jika dibandingkan dengan kontrol dengan area $18,3 \mathrm{~mm}$ relatif menunjukkan perubahan yang lebih bermakna.
Tabel 2. Daya hambat ekstrak daun alpukat dengan konsentrasi $80 \%$ terhadap pertumbuhan bakteri Streptococcus mutans

\begin{tabular}{cccc}
\hline No Pengukuran & $\begin{array}{c}\text { Daya Hambat } \\
\text { Terhadap Bakteri } \\
\text { Dengan Ekstrak } \\
\text { Daun Apukat (mm) }\end{array}$ & $\begin{array}{c}\text { Daya Hambat } \\
\text { Bakteri Pada } \\
\text { Kelompok } \\
\text { Kontrol } \\
(\mathrm{mm})\end{array}$ \\
\cline { 1 - 2 } & 31,4 & \\
\cline { 1 - 3 } 2 & $\mathrm{U} 1$ & 30,1 & 2 \\
\cline { 1 - 3 } 3 & $\mathrm{U} 2$ & 33,5 & \\
\hline Rata-Rata & 31,7 & \\
\hline
\end{tabular}

Tabel diatas menunjukkan bahwa zona blank setelah dilakukan perlakuan dengan konsentrasi $80 \%$ menunjukkan nilai rata-rata $31,7 \mathrm{~mm}$, dimana area terkecil pada $31,4 \mathrm{~mm}$, sedangkan area terluas $33,5 \mathrm{~mm}$. Kondisi ini jika dibandingkan dengan kontrol dengan area $21 \mathrm{~mm}$ relatif menunjukkan perubahan yang lebih bermakna.

Hasil penelitian menunjukkan bahwa dengan perlakuan pemberian ekstrak daun alpukat muda dengan dosis campuran $80 \%$ terjadi perubahan pada pemberian ekstrak daun alpukat terhadap daya hambat bakteri Streptococcus mutans didapatkan area daya hambat rata-rata sebesar 31,7. Sesuai klasifikasi daya hambat menurut Lade, dkk (2006) yang mengklasifikasikan zona hambat bakteri menjadi 3 kriteria yaitu sedang (6-9 $\mathrm{mm})$, kuat (10-14 $\mathrm{mm}$ ) dan sangat kuat (15$18 \mathrm{~mm}$ ). Hal ini disebabkan karena adanya beberapa kandungan aktif dari daun alpukat seperti flavonoid, saponin, alkoholid dan lain-lain. Adanya kandungan zat antibitotik dalam daun alpukat sebagaimana disebutkan dalam teori yang menjelaskan bahwa kandungan zat aktif yang terdapat di daun alpukat (Persea america miller) adalah flavonoid, quersetin. Flavonoid dalam tubuh manusia berfungsi sebagai antioksidan sehingga sangat baik untuk mencegah kanker. Manfaat flavonoid antara lain adalah untuk melindungi struktur sel, meningkatkan efektivitas vitamin C, anti inflamasi, mencegah keropos tulang, dan sebagai antibiotik. Flavonoid dapat berperan secara langsung sebagai antibiotik dengan mengganggu fungsi dari mikroorganisme seperti bakteri dan virus (Mursito, 2007) 
Hasil penelitian juga sesuai dengan penelitian sebelumnya yang menyatakan bahwa daun alpukat mengandung beberapa unsur yang dilakukan oleh Maryati, dkk. (2007) mengenai telaah kandungan kimia daun alpukat menunjukkan bahwa simplisia daun alpukat mengandung flavonoid, saponin, dan steroid atau triterpenoid.

Kandungan aktif dari daun alpukat akan membuat bakteri mengalami kerusakan pada dinding-dinding sel bakteri. Salah satu zat aktif yang bisa merusak dinding sel bakteri adalah flavonoid dan saponin. Sehingga dengan adanya kerusakan pada dinding sel bakteri, maka akan menjadikan bakteri di radius terdekat dengan perlakukan (ekstrak daun alpukat) mengalami kematian.

Adanya peran zat aktif diantaranya flavonoid dan saponin dalam daun alpukat sebagimana dijelaskan dalam teori yang menyatakan bahwa flavonoid menyebabkan terjadinya kerusakan permeabilitas dinding sel bakteri, mikrosom, dan lisosim sebagai hasil interaksi flavonoid dengan DNA bakteri, saponin termasuk dalam kelompok antibakteri yang menggangu permeabilitas membran mikroba, yang mengakibatkan kerusakan membran sel. Senyawa flavonoid berfungsi sebagai bakteriostatik dan mekanisme kerjanya mendenaturasi protein sel bakteri dan dapat merusak membran sitoplasma (Pelzar, 1996).

Teori yang lain disampaikan oleh Volk dan Wheeler (1988) dalam Prajitno (2007) menjelaskan bahwa senyawa flavonoid dapat merusak membran sitoplasma yang dapat menyebabkan bocornya metabolit penting dan menginaktifkan sistem enzim bakteri. Kerusakan ini memungkinkan nukleotida dan asam amino merembes keluar dan mencegah masuknya bahan-bahan aktif kedalam sel, keadaan ini dapat menyebabkan kematian bakteri.

\section{KESIMPULAN}

1. Ekstrak daun alpukat dengan konsentrasi $60 \%$ memiliki pengaruh dalam menghambat pertumbuhan bakteri
Sreptococcus mutans dengan rata-rata daya hambat sebesar 25,03 mm.

2. Ekstrak daun alpukat dengan konsentrasi $80 \%$ memiliki pengaruh dalam menghambat pertumbuhan bakteri Sreptococcus mutans dengan rata-rata daya hambat sebesar $31,7 \mathrm{~mm}$.

\section{DAFTAR PUSTAKA}

Antia, BS., Je Okokon, dan Okon PA, 2005, Hypoglycemic activity of aqueous leaf extract of Persea americana Mill. Research Letter, Volume 37, Issue 5, Page 325-326. www.ijponline.com

Hasbi, S., 2012, Uji Sensitivitas Perasan Daun Alpokat (Persea americana miller) terhadap Pseudomonas sp Metode Invitro. Karya Tulis Ilmiah. Akademi Analis Kesehatan. Banda Aceh.

Hawley, L.B., 2003, Mikrobiologi dan Penyakit Infeksi, Terjemahan oleh Brahm U Pendit, Hipokrates, Jakarta.

Jawetz, E., Melnick, J.L., dan Adelberg, E.A., 2005, Mikrobiologi Kedokteran Edisi 20, Terjemahan oleh Nani Widarini, EGC, Jakarta.

Lade, H.S., Chitanand,M.P., Gyananath, G., Kadam, T.A., 2006, Studies on Some Properties of Bacterocins Produced by Lactobacillus Species Isolated from Agro-Based Waste, The Internet Journal of Microbilogy, www.bioline.org

Maryati, S., Fidriany, I., dan Ruslan, K., 2007, Penelitian Obat Bahan Alam Sekolah Farmasi ITB. Telaah kandungan kimia daun alpukat (persea americana mill). Fakultas Farmasi, Bandung. Institut Teknologi Bandung. Skripsi. 
Miranda, M.M.F.S. S.S. Costa., M.G.M. Santos., M.H.C. Lagrota., A.P. Almeida., dan M.D. Wigg.,1997, In Vitro Activity Of Extracts Of Persea Americana Leaves On Acyclovir-Resistant And Phosphonoacetic Resistant Herpes Simplex Virus. Journal Phytomedicine, Vol. 4, hal 347-352.

Mursito, B., 2007. Ramuan Tradisional Untuk Pengobatan Jantung. Jakarta : Penebar Swadaya

Pelzar dan Chan, 1996. Dasar-dasar Mikrobiologi. Jakarta: UI Press.

Prajitno, A., 2007, Uji Sensitifitas Flavonoid Rumput Laut (Eucheuma Cottoni) Sebagai Bioaktif Alami Terhadap Bakteri Vibrio Harveyi. Skripsi. Fakultas Perikanan, Universitas Brawijaya

Undang-Undang Republik Indonesia Nomor 36 Tahun 2009 Tentang Kesehatan.

Waluyo, S., 2009, 100 questions \& answer diabetes. Jakarta: PT Elex Media Komputindo 